\title{
Management Model of Community Relations and Industries in Community College
}

\author{
Andi Muhammad Irfan, Andi \\ Muhammad Idkhan \\ Engineering Faculty \\ Universitas Negeri Makassar \\ Makassar, Indonesia \\ andimuhammadirfan@unm.ac.id
}

\author{
Eddy Sutadji \\ Engineering Faculty \\ Universitas Negeri Malang \\ Malang, Indonesia
}

\author{
Sunardi \\ Engineering Faculty \\ Universitas Negeri Gorontalo \\ Gorontalo, Indonesia
}

\begin{abstract}
This study aims to validate the management model of public relations and industry measurement in Community College in South Sulawesi. This research was conducted on Community College Sidenreng Rappang State and Community College Enrekang State in South Sulawesi Province. This research uses quantitative approach of non experimental design of survey type. Population in this research is 150 lecturers, instructors, and Community College students. The public relations management attribute and the Community College industry used as the manifest variable in this study consist of twelve indicators. The data analysis technique used is confirmatory factor analysis to confirm the dimensions developed in the factor. To interpret the results of research, then standardized loading factor $(\lambda)$ is used. The value used to estimate is $\lambda<0.50$ or $\lambda<0.70$ as the critical limit. The results showed that the charge factor or standardized loading factor $(\lambda)$ of each observed variable ranged from 0.57 to 3.06 and t-values ranged from 2.61 to 9.69. The factor load value meets the acceptance criterion of $\lambda \geqslant 0.50$. Similarly, the t-value also meets the acceptance criteria because the value is $\geqslant 1.96$. The result of manifest variable reliability calculation from public relations management and industry Community College shows reliability of 0.878 . This value meets the acceptance criteria of reliability $\geqslant \mathbf{0 . 7 0}$, so it is concluded that the reliability of the measurement model of latent variable of public relations management and Community College industry is good.
\end{abstract}

Keywords-management model, community college

\section{INTRODUCTION}

A Community College (CC) is a place to acquire the knowledge, technical and vocational skills that society and entrepreneurs need [1]. Meanwhile, Jacobs and Grubb [2] revealed that $\mathrm{CC}$ is a college venue to form basic skills, vocational and producing skilled workers in a particular field. The main objectives of community college colleges are to provide the necessary skills training on the job, and the opportunity for continuing post-secondary education before entering the labor market or continuing studies to higher education. There are three main objectives of the AK establishment: (1) providing higher education for underprivileged secondary school graduates, (2) providing youth with vocational and technical education, and (3) providing lifelong learning opportunities [3].

Public relation $\mathrm{CC}$ are always associated with all education stakeholders, including the Business World and the Industrial World (BW/IW). The activities are always related to the communication process of the vision, mission, and goals of the community college. Public Relations perform communication process between both parties as a medium to obtain the intersection of support and understanding from the parties concerned. According to [4] the management of education is seen from the nature of the problem consists of the fields of arable, namely: curriculum field, student field, personnel or human resources field, finance field, facilities and infrastructure, public relations. $\mathrm{CC}$ colleges have the following areas of management: (1) leadership management; (2) curriculum management; (3) learning management; (4) management of facilities and infrastructure; (5) public relations and industry management; (6) human resource management; (7) student management; (8) education quality management; (9) marketing management of alumni; and (10) financial management. One of the most important areas of management related to the implementation of $\mathrm{CC}$ is the management of public relations and industry.

Community school relations according to [5] is a form of shared responsibility between school and community towards the implementation of education. Through public relations it is expected to improve school cooperation with the community, especially parents, in order to improve the success of education in schools. School and community relations are very important, people here in the sense of business or industrial world. The collaboration of schools with the business world and the industrial world brings benefits to several parties.

According to [6] school cooperation with the business world and the industry must bring benefits to schools, learners and industry or companies. For schools to know information about the world of work that is relevant to the existing courses in school, for learners improve skills and experience working as an employee and for the business world / industry as a promotional company. [7] states that communicating with people outside the school is the fact that school is not something that stands apart from the outside world but is in a system of community that has been fixed.

Nasution8states that the execution of public relations activities externally implemented with the aim of strengthening relationships with communities or agencies outside the institution. The interest of the business world or the industrial world towards the school can provide benefits, as is the case in reference to the implementation of work practices in industry. In addition to schools, companies also benefit from school relationships with the business world, 
such as getting the source of manpower and expanding the company's promotion to the wider community.

Public relations is an art as well as a social discipline that analyzes trends, predicts every possible consequence of each activity, provides input and advice to organizational leaders, and implements planned programs of action to serve the needs of the organization and/or interests of its audiences [9]. Public Relations is a management function that evaluates public attitudes, identifies one's policies and procedures to the public, develops plans and runs a communication program to gain public understanding and acceptance [10]. Public relations is a management function that shapes and maintains a mutually beneficial relationship between the organization and society, which is the backbone of its success or failure [11].

In management practice, the position of public relations is placed in various positions. The diversity can generallybe identified, namely public relations as a separate section, into a department or a certain section such as entering in the department or part marketing, promotion, human resources and even in public relations agencies placed together with legal matters. The status and structure of public relations in management at a modern company is a member of a policymaking team that runs the company's wheels. It cannot be denied, however, that public relations are on the minor side in terms of authority [12].

The role of public relations and industry in higher education institutions is very important. How the management positioned public relations as a management tool is very determining output generated by the PR. The position and role of public relations can also be identified by the implementation of the work program, whether the public relations has a work program that is integrated with management policies or just a complement tool for the company's overall work program. The role of public relations in universities is: (1) fostering relationships and inward, outward and promoting, publicizing institutional activities as positive values; (2) being a mediator between the organization and its public; (3) neing a communicator, conception, mediator, problem solver depend on each institution; (4) seeing, hearing things related to the institution's image and being able to convey various information; (5) being mediator, spokesperson or institution representative in delivering information to the public; (6) being mediator, communicator, resource person from institution, as image for good image; and (7) in general are becoming agency imaging [13].

Public relations must perform its functions, namely: (1) public relations must master the relationship of organization to its environment; (2) public relations should work with organizational boundaries to build innovative solutions to organizational prob- ables; (3) public relations should think strategically, should be able to demonstrate knowledge of the mission, goals and strategy of the organization; and (4) public relations should be able to measure the success of a communication program [14].Four public relations jobs in an organization, namely: (1) cement and maintain the image of an organization, persona, product or service; (2) monitoring public opinion and delivering monitoring results to management; (3) provide advice management; and (4) inform the public about policies, activities, personality, products or services [12].

\section{METHOD}

This research uses quantitative approach of non experimental design of survey type. The population in this research is lecturer and instructor of Community Academy as much as 150 0rang. The research was conducted at CC Sidenreng Rappang State and CC Enrekang State in South Sulawesi Province. The attributes of CC curriculum management used as the manifest variables in this study consist of twelve indicators, namely: (1) identifying community and industry relations issues; (2) formulating the objectives of public relations and industry; (3) formulating work programs of public relations and industry; (4) determining the implementation strategy of public relations and industry; (5) establishing procedures for the implementation of public relations and industry; (6) establishing evaluation standards for the implementation of public relations and industry; (7) carrying out of public relations and industry internally; (8) executing public relations and industry externally (community, BW IW); (9) evaluating the implementation of BW IW cooperation; (10) following up the evaluation of the implementation of BW IW cooperation; (11) entering into MoU with BW IW; and (12) enhancing cooperation with BW IW. To test whether these manifest variables are valid and reliable indicators in explaining the construction of $\mathrm{CC}$ and community relations management variables, the data are analyzed by confirmatory factor analysis technique using LISREL 9.10 software.

Factor analysis is a measurement model to confirm the dimensions developed in the factor. To interpretresearch results, then used standardized loading factor $(\lambda)$. The value used to estimate is $\lambda<0,50$ or $\lambda<0.70$ as the critical limit 15 . If there is a $\lambda$ value smaller than the critical limit, then the observed variable can be erased from the model. In addition to the value $\lambda$ also used T-values with the criterion if there is at value of the factor load estimation $<1.96$, which means that the factor load estimation is not significant and the observed variable can be eliminated from the model.

\section{RESUlt AND Discussion}

Community and $\mathrm{CC}$ industry management consists of twelve components or observed variables: (1) identifying community and industry relations issues; (2) formulating the objectives of public relations and industry; (3) formulating work programs of public relations and industry; (4) determining the implementation strategy of public relations and industry; (5) establishing procedures for the implementation of public relations and industry; (6) establishing evaluation standards for the implementation of public relations and industry; (7) carrying out of public relations and industry internally; (8) executing public relations and industry externally (community, BW IW); (9) evaluating the implementation of BW IW cooperation; (10) following up the evaluation of the implementation of BW IW cooperation; (11) entering into MoU with BW IW; and (12) enhancing cooperation with BW IW. These components are presented in the management model of public relation and industry CC, in Figure 1.

Expert and user assessment results show that the components of the public relations model and the CC industry are categorized as feasible and highly feasible. The results of the CFA analysis show that the twelve components or indicators of public relations and $\mathrm{CC}$ industry are declared valid and reliable. This means that the twelve components or 
indicators are the factors that explain the public relations management and $\mathrm{CC}$ industry. Furthermore, descriptive analysis result shows that all components of public relations management model and $\mathrm{CC}$ industry have interest level with high and very high category, the indicator of cooperation through MoU with BWIW has the highest importance level and executing community and industry relation internally has the lowest importance level.

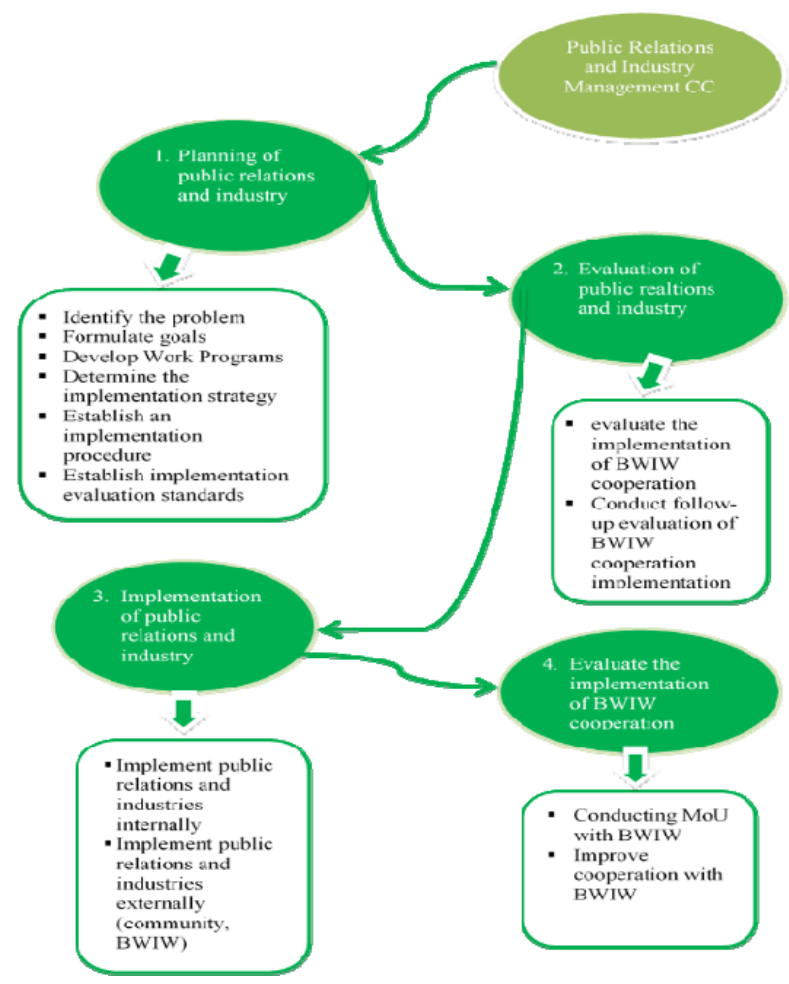

Fig. 1. The management model of public relation and industry $\mathrm{CC}$

To test whether the sixteen manifest variables are valid and reliable indicators in explaining the constructs of public relation and industry $\mathrm{CC}$ management variables, Confirmatory Factor Analysis was used. The results of data analysis is in the form of standardized solution as in Figure 1. Further summary of the results of analysis and interpretation of the validity and reliability of variables management of public relations and industry $\mathrm{CC}$ is presented in Table 1.

Based on the results of CFA analysis in Table 1 it is known that the charge factor or standardized loading factor $(\lambda)$ of each observed variable is in the range of 0.57 to 3.06 and the t-value ranges from 2.61 to 9.69 . The factor load value meets the acceptance criterion is $\lambda \geqslant 0,50$. Similarly, the t-value also meets the acceptance criteria because the value is $\geqslant 1.96$.

The results of the analysis show the twelve manifest variables, namely: identification of public relations and industry problems; purpose of public relations and industry; public relations and industry work program; implementation strategy of public relations and industry; procedures in the implementation of public relations and industry; standard of evaluation activity of public relations and industry implementation; implementing public relations and industries internally; execute public relations and industries externally (community, BWIW); evaluation of the implementation of BWIW cooperation; follow-up evaluation of the implementation of BWIW cooperation; MoU with BWIW; enhance cooperation with BWIW are valid variables in explaining the constructs of $\mathrm{CC}$ and community relationship management variables. The result of manifest variable reliability calculation from public relations and industry managementCC (PRIMCC) shows reliability of 0.878 . This value meets the acceptance criteria of reliability $\geqslant 0.70$,so it is concluded that the reliability of the measurement model of the latent variable of community and industry relationship management AK (PRIMCC) is good.

TABLE I. SUMMARY OF CFA RESUlTS OF PUBLIC RELATION AND INDUSTRY MANAGEMENT CC

\begin{tabular}{|l|c|c|c|c|l|}
\hline \multirow{2}{*}{$\begin{array}{c}\text { Variable Laten } \\
\text { VariableManifest }\end{array}$} & $\begin{array}{c}\text { Lambda } \\
(\lambda)\end{array}$ & $\begin{array}{c}\boldsymbol{t} \text { - } \\
\text { value }\end{array}$ & $\begin{array}{c}\text { Error } \\
(\boldsymbol{\delta})\end{array}$ & $\begin{array}{c}\text { Construct } \\
\text { Reliability }\end{array}$ & $\begin{array}{c}\text { Conclusi } \\
\text { on }\end{array}$ \\
\cline { 2 - 5 } & & & & 0,878 & Reliable \\
\hline MHMIAK $\rightarrow$ & 0,67 & 8.21 & 0,31 & & Valid \\
\hline MHMIAK1 & 1.11 & 6,26 & 1,90 & & Valid \\
\hline MHMIAK2 & 0,57 & 2,86 & 3,03 & & Valid \\
\hline MHMIAK3 & 0,91 & 8,65 & 0,48 & & Valid \\
\hline MHMIAK4 & 2,85 & 8,11 & 5,90 & & Valid \\
\hline MHMIAK6 & 0,81 & 8,74 & 0,37 & & Valid \\
\hline MHMIAK7 & 1,15 & 8,99 & 0,66 & & Valid \\
\hline MHMIAK8 & 0,99 & 5,44 & 2,15 & & Valid \\
\hline MHMIAK9 & 3,06 & 8,99 & 4,69 & & Valid \\
\hline MHMIAK10 & 0,87 & 9,69 & 0,28 & & Valid \\
\hline MHMIAK11 & 0,67 & 2,61 & 5,03 & & Valid \\
\hline MHMIAK12 & 1,55 & 8,29 & 1,63 & & Valid \\
\hline
\end{tabular}

The management of public relations and industry is concerned with maintaining good relations with the community. Good attitude management and community response will shape the goodwill of the community. The business/industry is the most important government and community partner in responding to government policies. Without the support of business/industry this policy will not go well. As one component of education, the industrial world has a strategic role in supporting the success of the education process. Rohiat16argues that the essence of school and community relations is to increase community involvement, awareness, ownership, and support.

Public Relations management is the management conducted by public relations officers related to the communication between the institution with internal and external parties to create a good relationship. In public relations management there are functions of planning, organizing, mobilizing or execution, and controlling 6 . Public relations is a management function that makes a mutually beneficial relationship between the organization and the community. Community relations help solve problems by applying management process stages, including: analyzing problems, planning and implementing and evaluating [11].

The dominant role of public relations in management is identified to four levels, namely: (1) expert prescriber, public relations officer is considered as an expert who can give advice to the leadership. This kind of role is needed in institutions that have many threats,and many / often undergo changes; (2) problem-solving facilitator, acting as a facilitator in the problem-solving process, public relations in every management, becoming a member of the team or a 
leader in the handling of cryptitis. This kind of role is needed for institutions with many threats but with little change; (3) communication facilitator, acting as a communication facilitator between the institution and public or as communication bridge and as intermediary or mediator in case of miscommunication. This kind of performanceis needed in companies that have fewer but much-changed threats; and (4) communication technician, acting as technical communication practitioner including providing technical layout. This kind of role is required for companies that have fewer threats and less change.[11].

\section{CONCULSION}

Based on the result of data analysis and discussion, it can be concluded that twelve manifest variables of public and industrial relationship management variables are: (1) identifying community and industry relations issues; (2) formulating the objectives of public relations and industry; (3) formulating work programs of public relations and industry; (4) determining the implementation strategy of public relations and industry; (5) establishing procedures for the implementation of public relations and industry; (6) establishing evaluation standards for the implementation of public relations and industry; (7) carrying out of public relations and industry internally; (8) executing public relations and industry externally (community, BW IW); (9) evaluating the implementation of BW IW cooperation; (10) following up the evaluation of the implementation of BW IW cooperation; (11) entering into MoU with BW IW; and (12) enhancing cooperation with BW IW are valid variables in explaining the constructs of public and industrial relations management variables. It can be seen from the value of factor loads meet the acceptance criteria is $\lambda \geqslant 0.50$. Similarly, t-value meets the criteria of acceptance for its value $\geqslant 1.96$. The reliability calculation of manifest variable shows reliability of 0.878 . This value meets the acceptance criteria of reliability $\geqslant 0.70$, so it is concluded that the reliability of the measurement model of latent variable of public relations and industry managemen tCC is good.

\section{REFERENCES}

[1] Emeagwali, N. S. Community Colleges Offer Baby Boomers an Encore. Tech. Connect. Educ. Careers82, 18-19, 2007.

[2] Jacobs, J. \& Grubb, W. N. Implementing the ' education consensus': The federal role in supporting vocational-technical education. (ERIC Clearinghouse, 2002.

[3] A'la, A. et al. UINSA emas menuju world class uinersity. 2016.

[4] Chang, C. T. et al. Journal of Environment and Earth Science.

[5] Wiyono, B. B. Partisipasi Masyarakat terhadap Pelaksanaan Kegiatan Pendidikan. J. Manaj. Pendidik.23, 1-9, 2010.

[6] Rosyadi, Y. I. \& Pardjono, P. Peran kepala sekolah sebagai manajer dalam meningkatkan mutu pendidikan di smp 1 cilawu garut. J. Akuntabilitas Manaj. Pendidik.3, 124-133, 2015.

[7] Chotimah, C. Strategi Public Relations Pesantren Sidogiri dalam Membangun Citra Lembaga Pendidikan Islam. Islam. J. Stud. Keislam.7, 186-210, 2012.

[8] Nasution, Z. Manajemen humas di lembaga pendidikan: konsep, fenomena, dan aplikasinya. (Universitas Muhammadiyah Malang Press, 2010.

[9] Anggoro, M. L. Teori dan Profesi Kehumasan serta aplikasinya di Indonesia. Bumi Aksara, 2000

[10] Datuela, A. Strategi Public Relations PT. Telkomsel Branch Manado dalam Mempertahankan Citra Perusahaan. J. ACTA DIURNA2, 2013.

[11] Cutlip, S. M., Center, A. H. \& Broom, G. M. Effective Public Relations, 2000.

[12] Bardhan, N. \& Sri Ramesh, K. Public relations in India review of a programme of research. J. Creat. Commun.1, 39-60, 2006.

[13] Luqman, Y. KOMPETENSI PRAKTISI PR DI KOTA SEMARANG 2012 (PADA BADAN USAHA MILIK NEGARA). J. Ilm. Komun. Makna2, 165-174, 2011.

[14] Elliott, G. \& Koper, E. Public relations education from an editor's perspective. J. Commun. Manag.7, 21-33, 2003.

[15] Wijanto, S. H. Structural equation modeling dengan Lisrel 8.8. Yogyakarta Graha Ilmu, 2008.

[16] Rohiat, D. \& Pd, M. Manajemen sekolah. Bandung PT Refika Aditama, 2010. 